\title{
GRAIN QUALITY DETERMINATION INDICATORS AND PROSPECTS FOR GRAIN EXPORT TO OTHER COUNTRIES
}

\author{
O. Shapovalenko, O. Yevtushenko, A. Petrenko, O. Shatkivska \\ National University of Food Technologies
}

\begin{tabular}{l} 
Key words: \\
Export \\
Grain \\
Physical properties \\
Chemical composition \\
\hline \multicolumn{1}{c}{ Article history: } \\
Received 11.01.2018 \\
Received in revised form \\
25.01.2018 \\
Accepted 08.02.2018 \\
\hline
\end{tabular}

Corresponding author:

O. Shapovalenko

E-mail:

npnuht@ukr.net

\begin{abstract}
The article presents the results of theoretical researches about the grain products' export to the EU countries and the problems of effective logistic activities.
\end{abstract}

On the experience of theoretical studies on the export of grain products to the EU countries and the problems of efficient logistics activities, statistics of the trade balance of grain crops and products of their processing are presented in the article. It is anticipated that the export potential of grain in Ukraine in the future may exceed 50 million tons, which will lead to higher revenues from external grain sales.

The following feed crops were selected for research: wheat, corn, soybeans, sunflower, flax. The determination of physical properties (humidity, volumetric mass, density) and chemical (raw protein, crude fat, crude fiber, crude ash, nonzinc extractive substances) properties were determined. In terms of humidity, all samples of examined grains are in a dry state. The volumetric mass of grain and seeds was in the range of $440-710 \mathrm{~kg} / \mathrm{m}^{3}$. The highest content of crude protein at the level of $39.5 \%$ was determined in coybean, which exceeds the corresponding indicator for corn by $28.3 \%$. Flax and sunflower predominate in the content of raw fat, respectively, soybeans in 2 and 3 times, and corn in 9 and 10 times. However, in flax seed, the largest amount of crude fiber is found in comparison with other crops $26.4 \%$, which is five times higher than that for soybeans $(5.3 \%)$ and may be an obstacle for its use in the manufacture of fodder. The maximal amount of non-base extraneous substances was determined in corn grain - 59.25\%, which is $52 \%$ higher than that for flax seeds. Thus, balancing the chemical indicators when making grain mixtures is more effective way to use investigated crops for the production of mixed fodders.

The presented experimental researches of physical and chemical properties of the most export-attractive grain raw materials have confirmed that there is a prospect of export of both the given products and products of its processing are real.

DOI: $10.24263 / 2225-2924-2018-24-1-28$ 


\title{
ВИЗНАЧЕННЯ ПОКАЗНИКІВ ЯКОСТІ ЗЕРНОВОї СИРОВИНИ ТА ПЕРСПЕКТИВИ ЇЇ ЕКСПОРТУ В ІНШ КРАÏНИ
}

\author{
О.І. Шаповаленко, О.О. Євтушенко, А.О. Петренко, О.М. Шатківська
}

Національний університет харчових технологій

У статті наведено результати теоретичних досліджень експорту зернових продуктів у країни СС, статистичні дані торговельного балансу зернових культур і продуктів їх переробки та визначено проблеми ефективної логістичної діяльності. Передбачається, що в майбутньому експортний потениіал зерна в Украйні може перевищити 50 млн $m$, щзо призведе до підвищення доходів від зовнішнього продажу зерна.

Для дослідження були обрані такі кормові культури: пшениия, кукурудза, соя, соняшник, льон. Проведено визначення фізичних (вологість, об 'ємна маса, щільність, крупність) і хімічних (сирий протеӥн, сирий жир, сира клітковина, сира зола, безазотисті екстрактивні речовини) властивостей. За показником вологості всі досліджені зразки зерна перебувають у сухому стані. Об'ємна маса зерна та насіння знаходилась у діапазоні 440-710 к2/ ${ }^{3}$. Найбільший вміст сирого протеїну на рівні $39,5 \%$ визначено в сої, що перевищує відповідний показник для кукурудзи на 28,3\%. Льон і соняшник переважають за вмістом сирого жиру, відповідно, насіння сої в 2 та 3 рази, а кукурудзу - в 9 та 10 разів. Однак у насінні льону спостерігається найбільша кількість сирої клітковини, якщо порівняти з іншими культурами, 26,4\%, що в п'ять разів перевищує такий показник для сої $(5,3 \%)$ і може бути перешкодою для використання його при виготовленні комбікормів. Максимальна кількість безазотистих екстрактивних речовин була визначена в зерні кукурудзи - 59,25\%, шзо на 52\% перевищує показник для насіння льону. Доведено, щуо збалансування хімічних показників якості при створенні зернових сумішей є більш ефективним способом використання досліджених культур для виробництва комбікормів.

Представлені експериментальні дослідження фізичних і хімічних властивостей найбільш експортно-привабливої зернової сировини підтвердили, щчо перспективи експорту як зазначеної продукиії, так і продуктів ї̈ переробки иілком реальні.

Ключові слова: експорт, зерно, фізичні властивості, хімічний склад.

Постановка проблеми. Лібералізація торгівлі з Європейським Союзом, яка передбачена в рамках поглибленої і всеосяжної зони вільної торгівлі, надасть національним виробникам ряд можливостей з нарощування експорту своєї продукції в країни-члени ЄС. 3 іншого боку, перед українськими експортерами стоїть низка викликів, які належить прийняти при виході на ринки країн-членів СС. Ці виклики лежать як у площині оптимізації самого бізнесу, так і в адміністративно-юридичних особливостей, таких як відповід- 
ність продукції, що експортується стандартам $Є С$, наявність необхідних документів і ліцензій для експорту тощо [1].

Україна входить у десятку найбільших світових виробників зерна і $\epsilon$ одним з лідерів експорту цієї сільськогосподарської продукції. Новий зерновий сезон тільки підтверджує попередні досягнення вітчизняних аграріїв (експорт зерна). Так, за прогнозами Міністерства сільського господарства США (USDA, серпень 2016 року) в 2016/2017 маркетинговому році (MP) Україна зберегла першу сходинку світового рейтингу виробників насіння соняшнику і експортерів соняшникової олії. При цьому частка вітчизняних аграріїв у світовому виробництві насіння соняшнику досягне $31 \%$, а в експорті соняшникової олії - 56\%. До того ж у новому зерновому сезоні Україна займає четверте місце світових експортерів кукурудзи, ячменю та жита, п’яте по сорго і вівса, шосте - з експорту пшениці [2].

Очікується, що до 2030 року експортний фонд зерна в Україні може перевищити 50 млн тонн. Доходи від зовнішнього продажу зерна зараз $є$ одними 3 найбільших серед українського експорту.

Основні проблеми експорту українського зерна - значні витрати i тривалість внутрішніх перевалок і транспортування зерна (аграрна логістика). Через невідповідність логістичних маршрутів сучасним вимогам аграрного експорту нинішні витрати на переміщення зерна від лінійних елеваторів до портів Чорного моря приблизно на $40 \%$ перевищують подібні витрати у Франції або Німеччині і на 30\% такі ж витрати в США.

Загалом високі логістичні витрати в Україні обумовлені досить низькою ефективністю логістики, що підтверджується оцінками міжнародних експертів. Так, з порівняльної ефективності логістики країн світу (визначалася в 2016 році за інтегральним показником Світового банку Logistics Performance Index LPI) Україна знаходиться лише на вісімдесятому місці і на третину поступається Німеччині, яка є лідером цього рейтингу.

Дотепер проблема 3 логістикою не так відчувалися зернотрейдерами, оскільки обсяги експорту зерна були значно меншими, а високі світові ціни на зерно з надлишком перекривали додаткові логістичні витрати. Однак порівняно з 2011 роком ціни світових ринків на зерно знизилися майже наполовину. Тому для утримання прибутковості виробництва зерна на належному рівні слід економити на логістичних витратах і розвивати перспективні напрямки вітчизняної логістичної інфраструктури (аграрна логістика).

Зернова логістична система України як необхідний елемент функціонування ринку зерна вимагає модернізації існуючих і введення в дію нових потужностей. Для цього потрібна виважена інвестиційна політика зацікавлених суб'єктів господарювання і держпідтримка.

Підвищення ефективності роботи логістичної інфраструктури з кожним роком стає все більш важливим для українських виробників зерна і їх конкурентоспроможності на світовому ринку (аграрна логістика). Впровадження інноваційних технологій у логістиці стимулюватиме подальше зростання експорту зерна з України. До того ж розвиток зернової логістичної інфраструктури забезпечує створення робочих місць, доданої вартості продукції, сприяє збільшенню надходжень до державного та місцевих бюджетів. 
Реформа держрегулювання повинна бути комплексною і спрямованою на максимально можливе усунення бар'єрів для приватних компаній, що працюють на ринку аграрної логістики і хочуть інвестувати в оновлення інфраструктури.

За офіційними даними Держстату України [3], за період з січня по листопад 2017 року підвищення експорту зернових культур проти аналогічного періоду 2016 року становило 9,9\%, а підвищення експорту продукції борошномельно-круп'яної промисловості - 34,3\%. Натомість спостерігався значний приріст імпорту цих видів товарів: зернові культури - 14,1\%; продукція борошномельно-круп'яної промисловості - 44,3\%. 3 огляду на це держава повинна зосередитися на проблемних аспектах розвитку інфраструктури. Це дасть можливість оптимально використовувати транспортний потенціал України і забезпечити максимально сприятливі умови транспортування для вітчизняних експортерів зерна. А отже, сприятиме утриманню рівня якості експорту зерна і нарощуванню обсягів українського зерна на світовому ринку [4]. Велику увагу треба приділяти упаковці та методам транспортування зернових продуктів.

Мета дослідження: аналіз фізичних і хімічних властивостей основної експортної зернової сировини та виявлення вагомих чинників заміщення транспортування сировини на продукти ії переробки.

Викладення основних результатів дослідження. Основними показниками, які впливають на ефективність транспортування зерна, $є$ фізичні властивості. Для дослідження були обрані такі кормові культури: пшениця, кукурудза, соя, соняшник, льон.

Кормову сировину оцінюють за такими основними видами показників: органолептичними (зовнішній вигляд, колір, запах); фізичними (вологість, об'ємна маса, щільність, крупність розмелу, металомагнітна домішка тощо) і хімічними (сирий протеїн, сирий жир, сира клітковина та інші). Всі дослідження фізико-технічних властивостей зернової сировини проводяться за чинними стандартами на кожний вид культури.

Фізичні властивості дослідних зразків наведені в діаграмах (рис. 1-3).

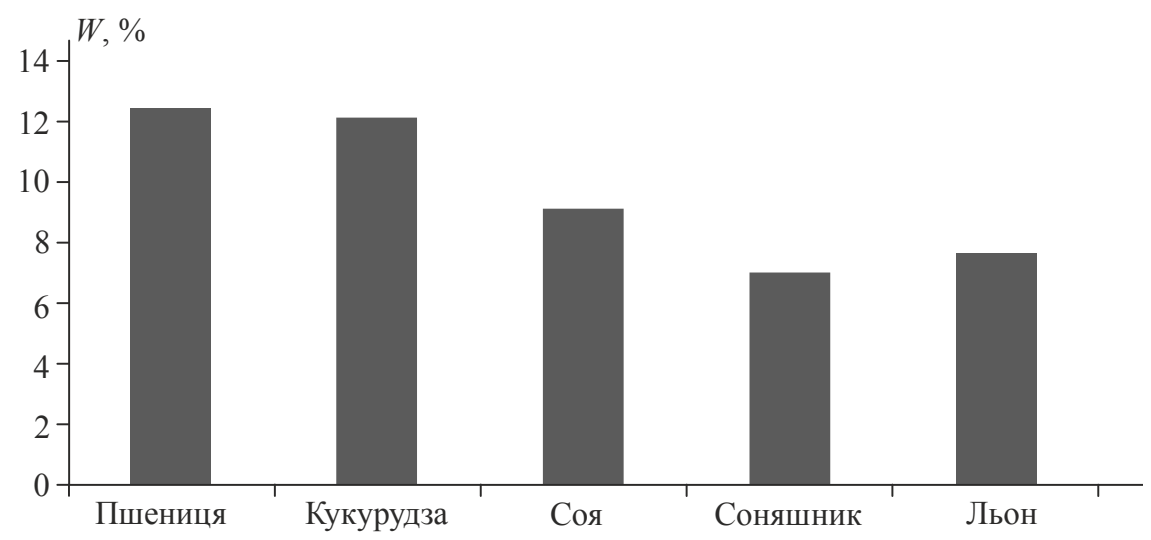

Рис. 1. Вологість зернових олійних культур 


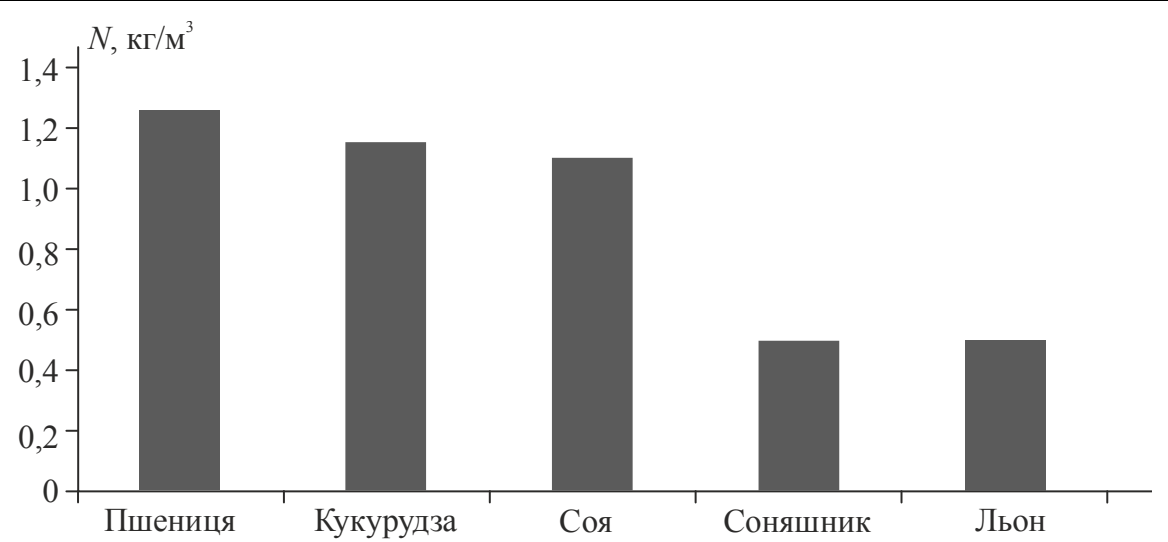

Рис. 2. Об'ємна маса зернових олійних культур

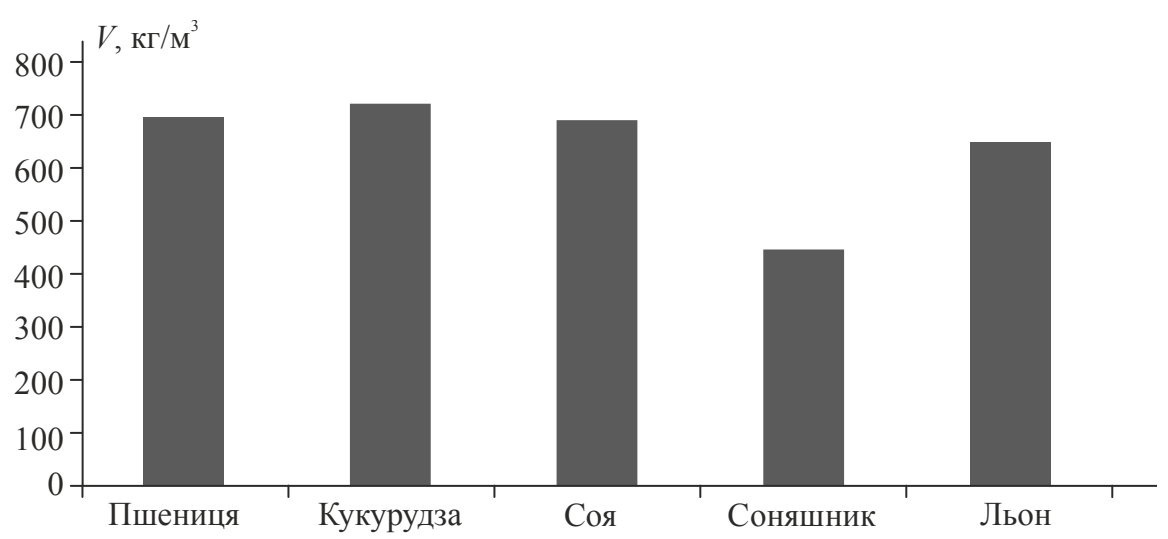

Рис. 3. Щільність зернових олійних культур

Визначення вологості зерна та насіння олійних культур було проведено за методикою чинних стандартів на кожну культуру. Зволоження змінює фізичні властивості зерна - зменшує опір роздавлюванню, збільшує еластичність оболонок. За високої вологості погіршується подрібнення, збільшуються витрати енергії, зменшується вихід готової продукції, погіршується ії якість.

При переробленні зерна від його вологості залежить опір подрібненню i, як наслідок, питома витрата енергії та продуктивність борошномельного обладнання.

Проведені дослідження (рис. 1) підтверджують, що за показником вологості всі досліджені зразки зерна знаходяться в сухому стані, оскільки обмежувальними нормами [5] для переходу в стан середньої сухості для пшениці і кукурудзи передбачено підвищення вологості до 14,0\%, для сої - до 12,0\%, а соняшнику і льону - до 11,0\%.

Об’ємна маса зерна характеризує виповненість і технологічну якість зерна. 3 проведених досліджень (рис. 2) видно, що об'ємна маса зерна та насіння коливається в межах 440-710 кг/ $\mathrm{m}^{3}$, що залежить від форми зерна, вологості, крупності, засміченості та виду домішок тощо. За об’ємною масою дослідже- 
ний зразок пшениці відповідає 2-му класу. Відповідно до держстандартів України показники об'ємної маси для інших дослідних зразків не нормуються.

Лінійні розміри зерна визначають його крупність, яка $€$ найважливішим показником якості зерна. У великому зерні більше ендосперму і менше оболонок, а отже, і вище вихід готових продуктів із зерна. Крупність пов'язана 3 хімічним складом зерна та іншими його характеристиками. Результати дослідження крупності зернової сировини наведено в табл. 1.

\section{Табличя 1. Крупність зерна і насіння}

\begin{tabular}{|c|c|c|c|}
\hline$№$ & Назва сировини & Схід із сита з вічками діаметром, мм & Кількість зерна, \% \\
\hline 1 & Пшениця & 3,0 & 95,9 \\
\hline 2 & Кукурудза & 7,0 & 88,3 \\
\hline 3 & Соя & 3,0 & 53,0 \\
\hline 4 & Соняшник & 6,0 & 86,0 \\
\hline 5 & Льон & 2,0 & 97,8 \\
\hline
\end{tabular}

Щодо показників щільності (рис. 3) та крупності (табл. 1) зерна, то отримані результати знаходяться на рівні менше 50\% діапазону середньостатистичних даних. Зокрема, для насіння сої регламентується прохід сита з вічками діаметром 3,0 мм відносити до сміттєвої домішки. Дана кількість сміттєвих домішок становить $47,0 \%$, що значно перевищує вимогу стандарту на рівні $10,0 \%$.

Показники хімічного складу зернових олійних культур наведені в табл. 2.

\section{Таблиця 2. Хімічні показники якості сировини}

\begin{tabular}{|c|c|c|c|c|c|c|}
\hline $\begin{array}{c}\text { Назва } \\
\text { культури }\end{array}$ & Вологість, \% & $\begin{array}{c}\text { Сирий } \\
\text { протеїн, \% }\end{array}$ & $\begin{array}{c}\text { Сирий жир, Сира клітковина, } \\
\%\end{array}$ & $\begin{array}{c}\text { Сира } \\
\text { зола, \% }\end{array}$ & $\begin{array}{c}\text { БЕР, } \\
\%\end{array}$ \\
\hline Соя & 12,0 & 39,5 & 17,30 & 5,3 & 5,20 & 20,70 \\
\hline Соняшник & 7,5 & 19,7 & 44,86 & 9,1 & 3,41 & 15,43 \\
\hline Льон & 7,1 & 20,1 & 35,20 & 26,4 & 3,95 & 7,25 \\
\hline Кукурудза & 13,7 & 11,2 & 4,30 & 10,3 & 1,25 & 59,25 \\
\hline
\end{tabular}

Аналіз результатів досліджень, наведених у табл. 2, свідчить про те, що зразки зернових культур відповідають за показниками якості вимогам нормативних документів. Найбільший вміст сирого протеїну на рівні $39,5 \%$ визначено в сої, що перевищує відповідний показник для кукурудзи на 28,3\%. Льон і соняшник переважають за вмістом сирого жиру, відповідно, насіння сої в 2 та 3 рази, а кукурудзу - в 9 та 10 разів. Однак у насінні льону спостерігається найбільша кількість сирої клітковини порівняно з іншими культурами $26,4 \%$, що в п'ять разів перевищує даний показник для сої (5,3\%) і може бути перешкодою для використання його при виготовленні комбікормів. Максимальна кількість безазотистих екстрактивних речовин була визначена в зерні кукурудзи - 59,25\%, що на $52 \%$ перевищувало даний показник для насіння льону $(7,25 \%)$. 


\section{Висновки}

Зернові культури за результатами аналізу фізичних властивостей мають перспективу щодо експорту в інші країни. Для їх переміщення може бути чітко визначена необхідна кількість транспортних засобів, а також необхідні розміри полотен решіток у сепараторах для їх очищення.

На основі проведених досліджень хімічних властивостей встановлено, що олійні зернові культури мають різне співвідношення основних показників хімічного складу, тому необхідні різні підходи до контролю показників їх якості в процесі зберігання.

Отримані результати дають змогу у подальшому розрахувати рецепти комбікормів для сільськогосподарських тварин і птиці, а також створити попередні суміші $з$ оптимізованим хімічним складом, що у підсумку надасть можливість підвищити пропозицію продукції зернопереробних підприємств 3 більшою доданою вартістю, розвинути ринок продуктів переробки в сучасних ринкових умовах та експорт цих продуктів.

\section{Лiтература}

1. Гид экспортера: какие документы и процедуры нужны для экспорта продукции в ЕС [Електронний ресурс]. — Режим доступу : http://www.bakertilly.ua/ru/news/id680. — 06.10.2017.

2. Звєрєва К. Ринок зерна України: від експорту сировини до готової продукції [Електронний ресурс]. - Режим доступу : http://agronews.ua/node/82481- 06.10.2017.

3. Товарна структура зовнішньої торгівлі у січні-листопаді 2017 року [Електронний pecypc]. — Режим доступу : http://www.ukrstat.gov.ua/operativ/operativ2017/zd/tsztt/tsztt_u/tsztt1117 u.htm. - 05.02.2018.

4. Маслак O. Логистика экспорта зерна в Украине [Електронний ресурс]. - Режим доступу : http://propozitsiya.com/logistika-eksporta-zerna-v-ukraine. — 06.10.2017.

5. Подпрятов Г.І. Технологія зберігання і переробки продукції рослинництва / Г.І. Подпрятов, Л.Ф. Скалецька, А.М. Сеньков // Практикум [Електронний ресурс]. - Режим доступу : https://studfiles.net/preview/5513372/page:5/. — 06.10.2017. 